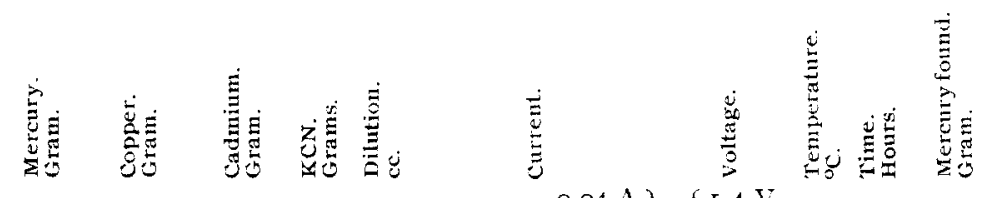

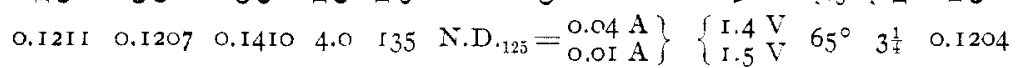

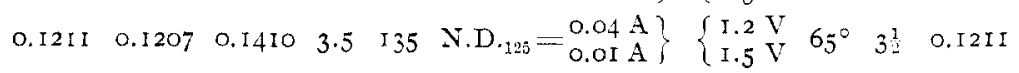

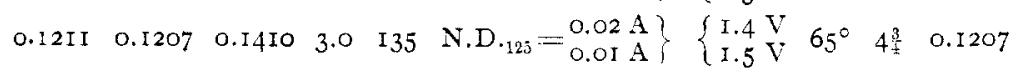

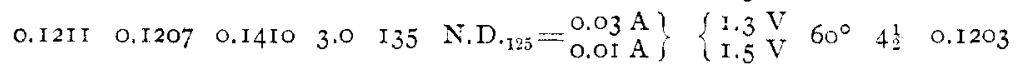

$$
\begin{aligned}
& \text { O.I2II } \left.0.1207 \text { U.I4IO } 3.0 \text { I35 N.D.125 }=\begin{array}{l}
0.04 \mathrm{~A} \\
0.01 \mathrm{~A}
\end{array}\right\}\left\{\begin{array}{lll}
\mathrm{I} .4 \mathrm{~V} \\
\mathrm{I.5} \mathrm{V}
\end{array} 60^{\circ} 4 \quad 0.1208\right.
\end{aligned}
$$

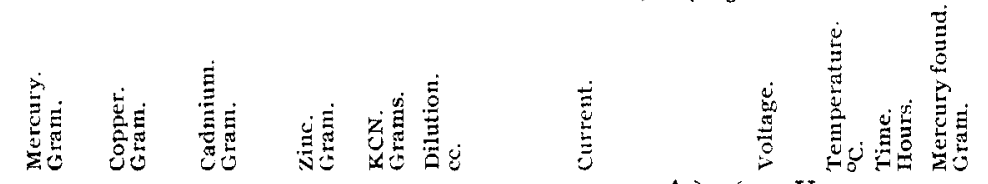

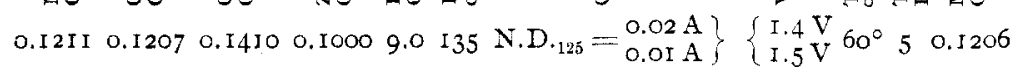

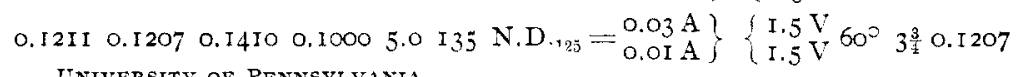

[CONTRIBUTION FROM THE JOHN HARRISON LABORATORY OF CHEMISTRY, No. 58.]

\title{
THE PRECIPITATION AND SEPARATION OF SILVER IN THE ELECTROLYTIC WAY.
}

By W. H. FULWEILER AND EDGAR F. SMITH.

Received June $45,190 t$.

\begin{abstract}
$T$ HE fact that silver can be quantitatively determined in the electrolytic way is well known. It has had ample confirmation in this laboratory, where numerous estimations of the netal in cyanide solution have been made. It is probable, too, that it was here that the first quantitative results with this electrolyte were obtained although it is customary to credit the method to Luckow notwithstanding, in his published account of the electrodeposition of silver from its double cyanide solution, he presents no quantitative data, and merely remarks in regard to such solutions: "So fällt aus solchen Lösungen das Silber gleichmässig in regulinischer form mit mattem Metallglanze nieder." " But be that as it may, without any further reference to the origin of the method, the latter is most deserving of consideration, and to

1 Ztschr. anal. Chem., 19, I5.
\end{abstract}


extend in some measure its general applicability we have made separations of silver from solutions in which three or four other metals were simultaneously present. It is the results in this direction which we most desire to put upon record.

Those interested in electrochemistry will at once recall that in the hundreds of separations made with the current more than two metals rarely were present in the electrolyte. Now that electrochemical analysis is daily becoming more prominent the proper working conditions for such problems should be ascertained. It is probable that this phase in electrolysis has been too long neg. lected. We give first results obtained with silver alone.

\begin{tabular}{|c|c|c|c|c|c|c|c|c|}
\hline & $\begin{array}{l}\text { Silver. } \\
\text { Gram. }\end{array}$ & $\begin{array}{l}\text { Dilu- } \\
\text { tion. } \\
\text { cc. }\end{array}$ & $\begin{array}{l}\text { Potassium } \\
\text { cyanide. } \\
\text { Grams. }\end{array}$ & $\begin{array}{l}\text { Current. } \\
\text { N.D. } 100 .\end{array}$ & Volts. & $\begin{array}{l}\text { Temper- } \\
\text { ature. }\end{array}$ & $\begin{array}{l}\text { Time. } \\
\text { Hours. }\end{array}$ & $\begin{array}{l}\text { Silver } \\
\text { found. } \\
\text { Gram. }\end{array}$ \\
\hline I $\ldots$ & 0.2133 & 125 & 2 & $0.03 \mathrm{~A}$ & 2.5 & $65^{\circ}$ & 4 & 0.2132 \\
\hline $2 \ldots$ & 0.2133 & I 25 & 2 & $0.03 \mathrm{~A}$ & 2.5 & $60^{\circ}$ & 3 & 0.2133 \\
\hline$\ldots$ & 0.2133 & 125 & 4 & $0.04 \mathrm{~A}$ & 2.5 & $60^{\circ}$ & 3 & $0.2 \mathrm{I} 3 \mathrm{I}$ \\
\hline $4 \ldots$ & 0.2133 & I 25 & 2 & $0.025 \mathrm{~A}$ & 2.7 & $60^{\circ}$ & 4 & 0.2134 \\
\hline $5 \ldots$ & 0.2133 & 125 & 2 & $0.025 \mathrm{~A}$ & 2.7 & $60^{\circ}$ & 3 & 0.2135 \\
\hline $6 \ldots$ & 0.2133 & 125 & 2 & $0.025 \mathrm{~A}$ & 2.7 & $60^{\circ}$ & 4 & 0.2125 \\
\hline
\end{tabular}

In trials $I$ and 2 the metal was precipitated upon a dish, while in 3 and 4 a plate cathode, and in 5 and 6 a cone was used to receive the silver, which was very adherent, and brilliant in luster. It was washed with water, alcohol, and ether.

The first thought was to further test the separation of silver from copper, making a special point in varying the quantity of the latter metal.

SIIVER FROM COPPER.

\begin{tabular}{|c|c|c|c|c|c|c|c|c|}
\hline $\begin{array}{l}\text { Silver. } \\
\text { Gram. }\end{array}$ & $\begin{array}{l}\text { Copper. } \\
\text { Gram. }\end{array}$ & $\begin{array}{l}\text { Potassium } \\
\text { cyanide. } \\
\text { Grams. }\end{array}$ & $\begin{array}{l}\text { Dilu- } \\
\text { tion. } \\
\text { cc. }\end{array}$ & $\begin{array}{l}\text { Current. } \\
\text { N.D.100. }\end{array}$ & Volts. & $\begin{array}{l}\text { Temper- } \\
\text { ature. }\end{array}$ & $\begin{array}{l}\text { Time. } \\
\text { Hours. }\end{array}$ & $\begin{array}{l}\text { Silver } \\
\text { found. } \\
\text { Gram. }\end{array}$ \\
\hline 0.1066 & 0.1053 & 2 & 125 & $0.021 \mathrm{~A}$ & 1.2 & $60^{\circ}$ & $4 \frac{7}{2}$ & 0.1066 \\
\hline 0.1066 & 0.1053 & 2 & I 25 & $0.02 \mathrm{~A}$ & 1.25 & $55^{\circ}$ & 6 & 0.1064 \\
\hline .1066 & 0.1053 & 2 & I 25 & 0.02 & I. 25 & $55^{\circ}$ & 6 & 0.1065 \\
\hline
\end{tabular}

The silver was completely precipitated. It was found to be free from copper.

The next ratio was I Ag : $2 \mathrm{Cu}$ :

\begin{tabular}{|c|c|c|c|c|c|c|c|c|}
\hline $\begin{array}{l}\text { Silver. } \\
\text { Gram. }\end{array}$ & $\begin{array}{l}\text { Copper. } \\
\text { Gram. }\end{array}$ & $\begin{array}{l}\text { Potassium } \\
\text { cyanide. } \\
\text { Grams. }\end{array}$ & $\begin{array}{l}\text { Dilu- } \\
\text { tion. } \\
\text { cc. }\end{array}$ & $\begin{array}{l}\text { Current. } \\
\text { N.D. } .100 .\end{array}$ & Volts. & $\begin{array}{c}\text { Temper- } \\
\text { ature. }\end{array}$ & $\begin{array}{l}\text { Time. } \\
\text { Hours. }\end{array}$ & $\begin{array}{l}\text { Silver } \\
\text { found. } \\
\text { Gram. }\end{array}$ \\
\hline I 066 & 0.2106 & 2 & 125 & $0.02 \mathrm{~A}$ & I. 25 & $60^{\circ}$ & $3 \frac{1}{2}$ & 0.1066 \\
\hline .1066 & 0.2106 & 2 & 125 & $0.02 \mathrm{~A}$ & I. 25 & $65^{\circ}$ & $3 \frac{1}{2}$ & 0.1065 \\
\hline
\end{tabular}


With the ratio $\mathrm{IAg}:{ }_{5} \mathrm{Cu}$ the results were:

\begin{tabular}{|c|c|c|c|c|c|c|c|c|}
\hline $\begin{array}{l}\text { Silver. } \\
\text { Gram. }\end{array}$ & $\begin{array}{c}\text { Copper. } \\
\text { Gram. }\end{array}$ & $\begin{array}{l}\text { Potassium } \\
\text { cyanide. } \\
\text { Grams. }\end{array}$ & $\begin{array}{l}\text { Dilu- } \\
\text { tion. } \\
\text { ce. }\end{array}$ & $\begin{array}{l}\text { Curretet. } \\
\text { N.D. }\end{array}$ & Volts. & $\begin{array}{l}\text { Temper- } \\
\text { ature. }\end{array}$ & $\begin{array}{l}\text { Time. } \\
\text { Hours. }\end{array}$ & $\begin{array}{l}\text { Silver. } \\
\text { found. } \\
\text { Gram. }\end{array}$ \\
\hline 0,1066 & 0.5265 & 4 & I 25 & $0.03 \mathrm{~A}$ & 1.2 & $65^{\circ}$ & 31 & o. 1066 \\
\hline 0.1066 & 0.5265 & 4 & 125 & $0.02 \mathrm{~A}$ & I. 2 & $60^{\circ}$ & $3 \frac{1}{4}$ & o. 106 \\
\hline
\end{tabular}

The experience gathered from these determinations show's that the separation of these two metals can be conducted in this particular way with the certainty of success. In several instances the liquid from the silver was diluted to $500 \mathrm{cc}$. and electrolyzed with a more powerful current when the copper was fully precipitated and showed the absence of silver upon applying the customary tests.

Silver from Copper and CADMIUM.

\begin{tabular}{|c|c|c|c|c|c|c|c|c|c|}
\hline$\frac{5}{50}$ & 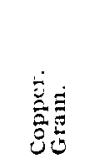 & 总 & 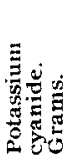 & نُ & 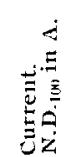 & $\frac{d}{0}$ & 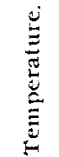 & 总 & 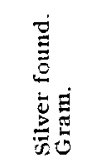 \\
\hline 0.1066 & 0.1053 & O. I I 28 & 3 & I25 & 0.02 & I. 25 & $65^{\circ}$ & $3_{4}^{3}$ & $0 . \log _{3}$ \\
\hline 0.1066 & o. 1053 & 0.1128 & 3 & I 25 & 0.015 & 1.25 & $65^{\circ}$ & 4 & 0.1069 \\
\hline 0.1090 & 0.1053 & O. I I 28 & 3 & 125 & 0.02 & I. 25 & $65^{\circ}$ & 4 & \\
\hline
\end{tabular}

The next step was the introduction of a zinc salt into the electrolyte. Strangely enough some cadmium was now found in the deposit of silver, but it was not long before the observation was made that if the electrolyte was heated to $75^{\circ}-80^{\circ}$ before passing the current the co-precipitation of cadmium could be absolutely prevented. The conditions are indicated in the subjoined table:

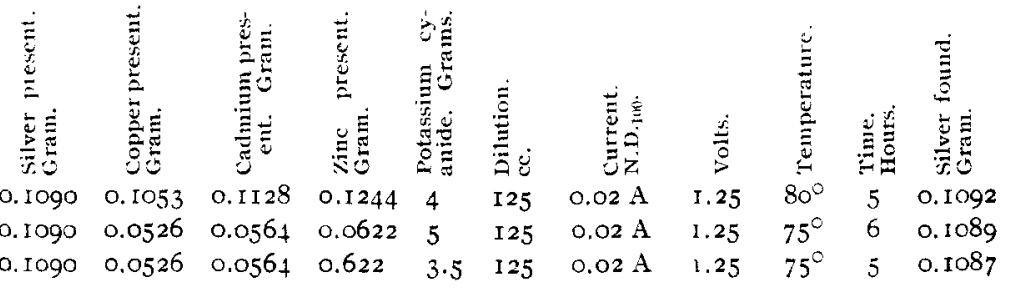

The silver was found free from any of the other metals. In all the experiments made with the conditions as recorded in the preceding paragraphs the striking, brilliant luster of the deposited silver was particularly marked. 
Silver from Copper, Cadmium, Zinc, aNd Nickel.

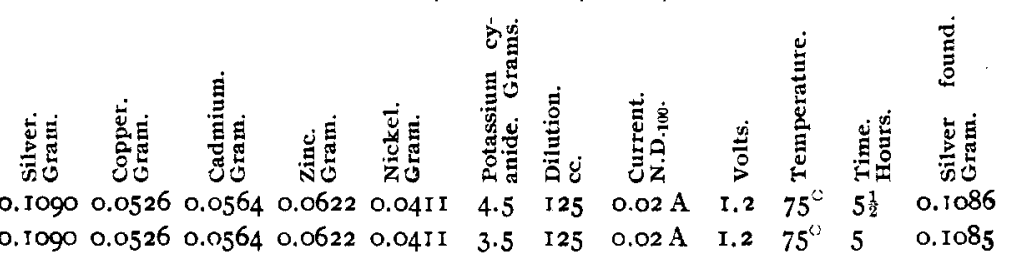

None of the other metals were found in the silver deposit. The addition of the nickel to the solution seems to retard the precipitation of silver to a slight degree.

University of Pennsyluania.

\title{
NOTES ON THE ANALYSIS OF EXPLOSIVES.
}

\author{
By F. W. Smith.
}

Received May 15, 19oI.

DETERMINATION OF SULPHUR.

IN gelatine dynamite containing from I to 3 per cent. of sulphur, the following method is useful: Weigh out about 2 grams into a silver crucible of $100 \mathrm{cc}$. capacity : fill it two-thirds full with an alcoholic solution of caustic soda. Warm carefully on a water-bath until the nitroglycerine is decomposed and then evaporate to dryness. Add next about 4 o grams of solid caustic potash and 5 grams of potassium nitrate. Fuse the contents of the crucible carefully over a blast-lamp until all organic matter is oxidized. Dissolve in dilute acetic acid, filter from a small amount of insoluble matter, and precipitate the sulphates with the usual precautions. The results check very closely.

AN INDIRECT METHOD FOR THE ESTIMATION OF NITROGLYCERINE IN GELATINE DYNAMITE, ETC.

About 15 grams of the sample are completely extracted with chloroform in a Soxhlet apparatus and the loss in weight noted. In another portion the moisture is determined by desiccation over sulphuric acid for five days, careful experiments having shown that nitroglycerine is not appreciably volatile in a desiccator. Another portion of about 2 grams is carefully extracted with pure ether by maceration in a small beaker. The ether is poured through a filter and the extraction repeated three or four times. The filtrate is now allowed to evaporate spontaneously or with the aid of a gentle current of air. When the 